\title{
MANAJEMEN KRISIS DI SEKTOR INDUSTRI MENGHADAPI ERA PANDEMI
}

\author{
Hendra Suwardana Abdul Wahid Nuruddin \\ Fakultas Teknik, Universitas PGRI Ronggolawe \\ e-mail: suwardanahendra@gmail.com
}

\begin{abstract}
Today, the world's life experiences a disaster that could never have been imagined to have occurred at the end of the 21 st century, where the Covid 19 pandemic event just came without knowing when it would end. This incident became a turning point for all sectors of life, especially health and the economy. The industrial sector has been the hardest hit and the crisis has reached an acute to the chronic stage. This is where innovative progressive leadership is needed to solve this crisis into a recovery phase and become a turning point for the awakening with post-pandemic adaptive behaviour change. In the following year, the pandemic will come back in a different form, thus demanding the readiness and readiness of the stakeholders to prepare from now on through the crisis centre. The industrial sector needs to understand the advantages of each comparative advantage and be willing to collaborate to complement each other's strengths and weaknesses or mutually subsidize competitiveness.
\end{abstract}

Keywords: pandemic; management; crisis; industry

\begin{abstract}
ABSTRAK
Kehidupan dunia dewasa ini mengalami perubahan mendasar dalam tata kelola kehidupannya akibat wabah pandemi covid 19. Semua pemangku kepentingan tidak ada yang mengerti kapan musibah ini akan berakhir, tapi mereka mengetahui secara pasti bahwa pola kerja manajerial dalam semua lini hidup harus berubah apabila tetap ingin bisa eksis dan beraktifitas. Pandemi covid 19 ini dapat disebut sebagai fenomena yaang monumental diabad 2, karena khususnya sektor infudtri dituntut dapat menjaga kesinambungan laju profuktivitasnya. Krisis kesehatan ini telah melahirkan multi dimensi krisis sendi kehidupan dan saling terkait. Dunia industri menjadi paling terpukul akibat krisis tersebut dan yang terjadi sudah pada tahapan akut menuju kronis. Disinilah kebutuhan studi kepemimpinan yang inovatif- progresif menjadi sangat mendesak bagi semua pemangku kepentingan agar dapat menyelesaikan krisis ini. Metode kepemimpinan yang efektif akan dilihat dari kemampuan manajemen yang adaptif pada perubahan dan kolaboratif pada sumber daya agar menemukan daya saing dengan cara keunggulan kompetitif yang dimiliki. Bagi sektor industri kemauan saling mendistribusi keunggulan dapat secara efektif menutup sisi in-efesiensi dan tercapainya keuntungan yang maksimum.
\end{abstract}

Kata kunci: pandemi; manajemen; krisis; industri

\section{PENDAHULUAN}

Dunia mengalami perubahan yang belum pernah terbayangkan sebelumnya atau hanya sebatas sebuah cerita fiksi imajinatif dalam dunia perfilman. Seluruh sendi kehidupan terasa luluh lantak tidak berdaya menghadapi pandemi Corona Virus Disease 2019 (Covid-19). Pandemi ini menyebar sangat cepat-exskalatif dan masif melebihi lonjakan deret ukur dan menyebabkan perubahan sosial dari piranti kehidpan semula yang ada menjadi tidak ada atau sebaliknya, dari semula yang tidak ada menjadi ada. Berawal dari krisis kemanusiaan hilangnya banyak jiwa menjadi krisis kehidupan multidimensi yang seolah tak berujung dan berakhir.
Pada pertemuan di Jenewa tanggal 7 September 2020 Ketua Organisasi Kesehatan Dunia (World Health Organization/ WHO) Tedros Adhanom Ghebreyesus menyampaikan bahwa kiranya dunia harus lebih bersiap menghadapi pandemi -pandemi berikutnya pasca ditemukannya vaksin Covi-19. Pandemi berikutnya semakin destruktif dan unpredictable, yang bisa dipastikan bahwa perkembangan virus semakin canggih dan tidak berpola. Bahkan, Profesor Sarah Gilbert dari Oxford University meyakini kedepan pandemi infeksi virus akan bersifat zoonist, artinya akibat pola hidup manusia dewasa ini, maka penularan pandemi akan dari hewan kepada manusia (detikhealth.com, 2020). 
Sedangkan laporan WEF (Word Economic Forum) pada 21 April 2020 menyampaikan temuan akan ada 347 resiko atas pandemi ini, khususnya pada 5 (lima) bidang besar yang mengalami resiko tersebut antara lain; sosial-ekonomi-teknologi dan lingkungan-kawasan (teknoia.com, 2020). Berdasar laporan Yelp: Local Economic Impact Report tanggal 25 Juni 2020 memaparkan sektorsektor industri yang paling berdampak dari pandemi Covi-19 hingga sektor usaha yang justru mengalami kenaikan permintaan tapi pada intinya satu bahwa perilaku konsumen mengalami perubahan dan suatu pandemi hakikatnya adalah krisis ekonomi (elpeconomicaverage.com, 2020).

Laporan dari OECD (Organisation for Economic Co-operation and Development) yang terpublikasi tanggal 23 April 2020 menyatakan bahwa pandemi ini berimplikasi terhadap ancaman krisis ekonomi yang sangat besar dan belum pernah terjadi sebelumnya yang ditandai dengan jatuhnya daya beli masyarakat, hilangnya kepercayaan konsumen, ketakutan dan ketidakpercayaan pada lingkungan sekitar dan ujungnya tidak ada kepastian. OECD memperkirakan angka turunya produktifitas bisa mencapai lebih separoh dari biasanya dan bagi Indonesia yang paling merasakan ada di sektor pariwisata, perdagangan dan investasi. (Aknolt Kritian, 2020). Begitu juga Laporan Kementerian Keuangan Republik Indonesia mengenai Pertumbuhan PDB (Product Domestic Brutto) Negara-Negara (year on year) April 2020 dampak krisis global akibat pandemi akan menyebabkan kontraksi / penurunan ekonomi dunia sebsar -2,0\% sampai $-2,8 \%$ atau setara dengan jumlah 195 juta orang akan kehilangan pekerjaan dan 580 juta orang jatuh miskin (Mohammad Ikhsan, 2020).

\section{METODE PENELITIAN}

\section{Kerangka Penetapan Strategi Manajemen Krisis}

Krisis sejatinya juga merupakan katalis bagi semua stakeholder untuk mampu melewati menjadi lebih adaptif dan solutif. Jalan yang diambil melakukan transformasi nilai inovasi untuk merubah tata kerja yang efektif dan efisien. Pada kondisi krisis akan ditemukan semua persoalan yang terurai dengan sendirinya, mulai dari masalah yang berkembang, sorotan publik terhadap masingmasing kinerja organisasi, perilaku masyarakat yang berbeda dan kuatnya itervensi pemerintah dalam menentukan kebijakan (Hafid, 2020).

Mengkontekstualiasi situasi krisis diperlukan strategi yang cepat, tepat dan manfaat. Sun Tzu
Manajemen Krisis di Sektor Industri... (Hendra Suwardana, Abdul Wahid Nuruddin)

dengan karya legendaris. The Art of War oleh Tan, 2011 merumuskan langkah memenangkan pertempuran / situasi sulit dengan cara empat hal antara lain: membuat perencanaan, menilai persaingan pasar, layanan prima, dan branding. Pertama, fase perencanaan merupakan fase penentu yang membahas kajian dari awal mulai produksi hingga sumber daya dan sumber dana yang diperoleh sampai pada tahap jalan menguasai pangsa pasar. Kedua, menilai persaingan pasar. Kemenangan akan diperoleh apabila lebih mengenal diri sendiri dengan segala sisi plus dan minusnya sebelum mengenali kemampuan kompetitor. Secara sederhana tapi simultan dirumuskan dalam tata kelola mengerti SWOT (Streght, Weakness, Oppurtunity dan Threat). Sisi S-W (Streght dan Weaknes) adalah sisi raport internal, sedang O-T (Oppurtunity dan Threat) adalah sisi raport eksternal. Tanpa mengerti S-W tidak akan mampu mengerti sisi O-T. Ketiga, layanan prima. Kemenangan hebat itu diperoleh bukan dari agresifitas ekpansi tapi justru diperoleh dengan kesadaran para kompetitor untuk berkolaboratif menjalankan usaha secara seksama. Keempat branding. Hasil dari persepsi masyarakat terhadap produk yang dipakai akan menghasilkan nilai dan itu disebut branding sebagai kapitalisasi benefit yang dinikmati secara kontinuietas.

Berangkat dari teori Fink, 2000 maka kerangka penetapan strategi manajemen krisis seperti pada Gambar 1

\section{PEMBAHASAN}

\section{Manajemen Krisis}

Ungkapan tidak ada yang abadi berubah di dunia ini kecuali perubahan itu sendiri "Nothing endures but change" tampak nyata dan mutlak sebagaimana yang dikatakan Filsuf Yunani, Heracletos (Dita Widya Tan, 2011). Manusia pada dasarnya akan mengalami perubahan dan dituntut adaptif atau evolutif terhadap lingkungan sekitar yang terus tumbuh dan berkembang dan ini sebagai rangkaian makna proses dari derajat kecepatan, irama hingga tersusun harmoni pada tingkat saling "berdamai" menerima keadaan untuk hidup berdampingan. Ragam persoalan dapat diselesaikan secara transformatif yang kadangkala mengubah wajah total dari sebelumnya. Seorang ahli sejarah Yuval Noah Harari menulis artikel yang dipublikasi oleh Finansial Times pada 20 Maret 2020 dengan judul The World After Coronavirues menyebutkan badai pasti berlalu dan dunia yang ditempati sekarang akan berubah dari sebelumnya (Hendra Puji, 2020). 
Diluar sektor kesehatan yang mengalami dampak luar biasa, senyampang itu dan beririsan simitris sektor ekonomi mengalami kontraksi menuju krisis multi demensi ekonomi secara global dan tidak ada negara manapun yang terhindar. Berdasar data April Tahun2020 dari World Economic Outlook, International Monetary Fund (IMF) menyebutkan perekonomian dunia merosot hingga minus tiga persen $(-3 \%)$. Secara umum sektor industri mengalami pertumbuhan negatif ke arah minus, meskipun ada bebeapa sektor justru menglami pertumbuhan positif semisal farmasi atau tekstil. Berdasarkan data dari hasil survey tanggal 14 April 2020 oleh Kantor World Panel Indonesia bahwa untuk mampu tetap tumbuh dan berkembang sektor Industri Indonesia harus mencontoh Tiongkok dimana pola perubahan perilaku konsumen diadopsi dalam manajerial sektor pengolahan industri dengan rumusan formulasi manajemen krisis yang sudah menjadi adigium hukum ekonomi bahwa dengan modal sekecil-kecilnya memperoleh maksimalisasi keuntungan atau (low budegt - high impact) (Tempo.co.id, 2020).

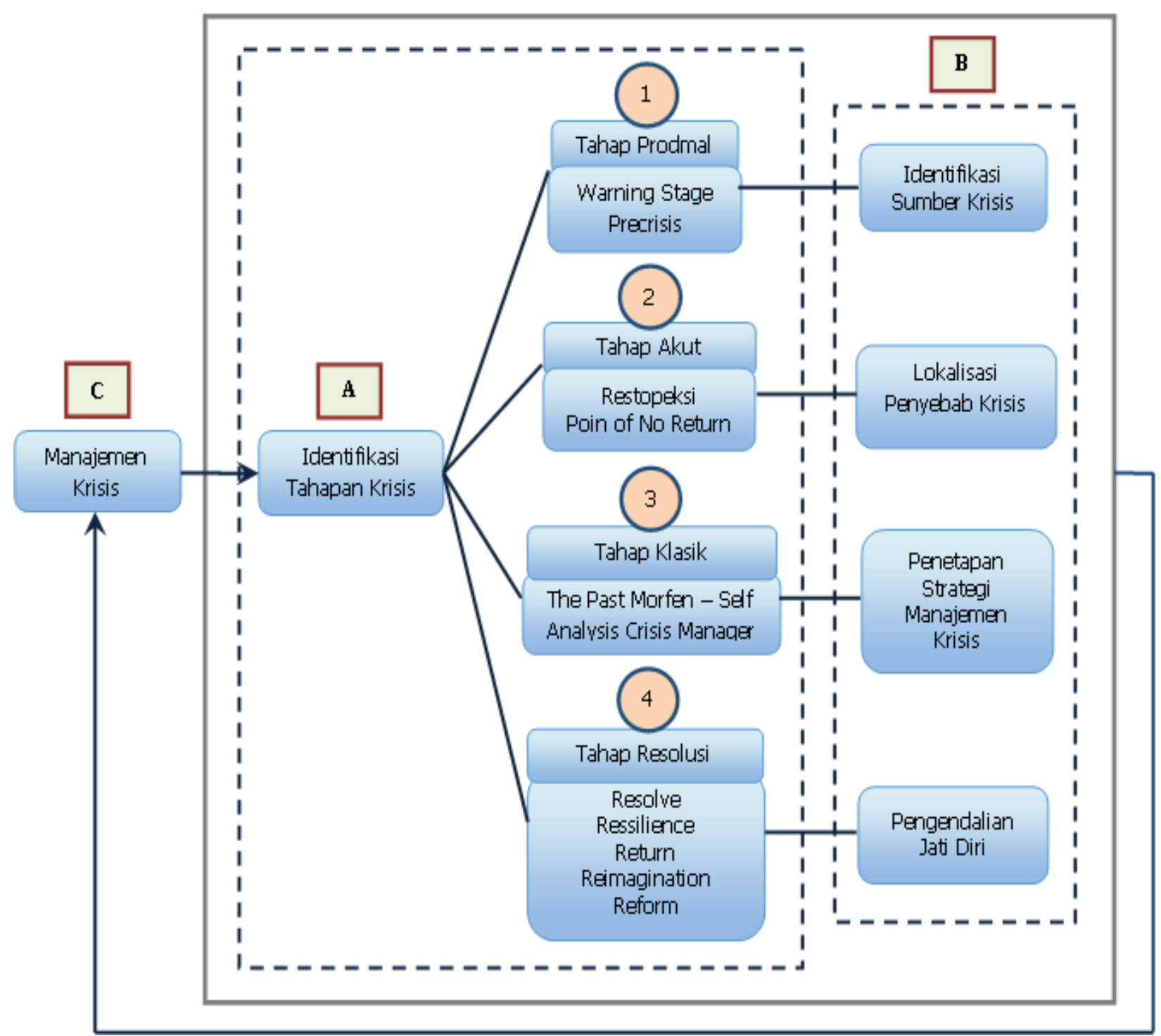

Kerangka Penetapan Strategi Manajemen Krisis

Fink, 2000 (diolah)

Mengurai permasalahan manajemen krisis perlu diawali dengan pengertian krisis. Secara etimologis kata krisis berasal dari bahasa Yunani krinein yang bermakna keputusan, sedangkan secara terminologi krisis menurut Argenti, 2009 bermakna suatu kejadian yang bersifat malapetaka baik secara natural, sebab-akibat, human error atau kesengajaan. Secara konklusif rumusan diatas 
p-ISSN 1693-1378

e-ISSN 2598-9952

maka krisis dapat dijelaskan dalam dua prespektif yakni alami dan kesengajaan dan manajemen krisis hakikatnya adalah respon dari perubahan sekitar yang cenderung bersifat negatif, bahkan bisa mendekonstruksi pilar-pilar penyangga tegaknya sebuah organisasi, kata Berton, 1993. Pada titik kondisi tersebut memerlukan sentuhan peran pokok fungsi manajemen dalam mengambil, menerima dan mengelola resiko (risk maker dan risk taker) yang menghadirkan dukungan seluruh stakeholder untuk mencari titik keseimbangan (equiblirium) mampu keluar dari arus turbolensi. Peran komunikasi menjadi titik penting melewati persoalan ini, kata Gregory, 2008 dan Fajar, 2011.

Manajemen krisis dapat dimaknai sebagai fenomena besar terhadap sebuah organisasi yang mengancam merugikan hingga mematikan, sedangkan nhumenanya yang tampak adalaah dimana situasi ketidakpastian (uncertainty). Setidaknya ada tiga (3) unsur pokok yang termuat didalam situasi krisis ialah kejutan (kaget/ sudenly), waktu yang singkat dan beresiko kompleksitas.

Mengadopsi model anatomi penyelerasan manajemen krisis menurut Steven Fink, 2000 bahwa kategorisasi kondisi pandemi ini yang berimpilkasi pada sektor industri sudah dapat disebut memasuki domain tahap akut menuju kronis. Fenomena instabilitas dari waktu ke waktu baik mulai samar menjadi terang-benderang menjadi suatu kondisi yang dapat dirasakan oleh semua pihak dan saling mempunyai pengaruh (interdependensi) pada sisi likuiditas. Tahap ini juga disebut The Point of No Return yang berarti kondisi sektor kehidupan sebelum dan pasca pandemi akan sangat berbeda dan tidak sama kembali (Fink, 2000).

Kemampuan bertahan hidup sangat diterminan dari kecepatan dan kesigapan intensitas mengelola komplesitas krisis bukan sekadar menerima krsisis. Tahap akut ini bisanya berdurasi pendek tapi sangat deterministik, karena pada kondsi ini semua orang sudah merasa letih, tidak berdaya dan cenderung pesimistik menerima realitas sekitar atau dengan istilah umumnya "hidup enggan, mati tak mau". Kehandalan manager untuk mempercepat pengakhiran kondisi ini akan semakin cepat menumbuhkan semangat positivistik dan berdaya-saing berdasar keunggulan yang ditemukan (competitive advantage).

Tahapan transformasi industri dalam melewati masa pandemi ini menurut Menteri Perindusstrian Agus Gumiwang (pasardana.id, 24 Juli 2020) ada lima (5) $\mathrm{R}$ sebagai langkah kongrkit (Resolve,
Manajemen Krisis di Sektor Industri... (Hendra Suwardana, Abdul Wahid Nuruddin)

Resillience, Return, re-Imagination dan Reform). Pertama, resolve yang berarti menangani pandemi berdasar partisippasi publik, khususnya karyawan dengan menumbuhkan rasa kesadaran diri untuk saling merasa memiliki dengan menerapkan cara hidup/ bekerja sesuai protokol kesehatan. Kedua, resillience yang berarti memperkuat kemampuan perusahaan bertahan dengan menemukan keunggulan berdaya saing dan berinovasi. Ketiga, return yang berarti kembali beraktifitas menjaga likuiditas arus (cash flow) dengan produktifitas berdasar sumber daya yang dimiliki dan inovasi yang telah ditemukan. Keempat, reimagination yang berarti melakukan re-branding atau repositioning dengan cara menerapkan pola hidup yang mengakselerasi hasil inovasi dengan kebutuhan pasar untuk mengembalikan citra dan kepercayaan publik. Kelima, reform yang berarti adaptasi yang bertransformasi model bisnis sesuai revolusi industri 4.0.

\section{PENUTUP \\ Kesimpulan}

Komitemen dari manajemen sangat dibutuhkan secara konstan untuk melakukan evaluasi secara berkala terhadap dinamika kekinian terhadap problem solving yang berkembang di perusahaan. Jalur kecepatan informasi menjadi kendali penting untuk mengambil kebijakan. Sistem informasi hendaknya menjadi software screening atas tindakan yang akan diputuskan. Manajemen menempatkan diri pada wilayah crisis reponses, yang artinya selalu tanggap dan sigap dalam mengahdapi krisis.

Pada aspek krisis yang terpukul bukan hanya pada permintaan dan penawaran (suplly- demand), tapi hantaman krisis akibat pandemi itu akan mengarah pada tiga (3) hal pokok, antara lain: pertama, yang paling terpukul adalah sektor industri manufaktur terutama padat karya akibat adanya kebijakan pembatasan jumlah kelompok perorangan. Kedua, menurunnya angka PDRB (Produc Domestic Ratio Brutto) dimana akibat karantina wilayah, maka tingkat produktifitas terhadap barang dan jasa menjadi sangat terbatas. Ketiga, penurunan aktivitas sosial ekonomi dengan ditandai turunnya jumlah konsumsi masyarakat akibat hilangnya daya beli.

Pada kondisi krisis yang harus diperhatikan adalah kesepahaman mengenai skala prioritas penangan dan pengangggaran yang tepat dan merfleksikan kebutuhan dasar dan keberpihakan pada sisi mempertahankan kelangsungan kemampuan produktifitas pekerja/ masyarakat agar 
krisis ekonomi tidak berubah menjadi krisis multi dimensi. Sehingga penyusunan prioritas dan pengaggaran dilakukan secara seksama dan menjadi jalan arah (roadmap) menuju pada era pemulihan, tapi juga pada era penguatan dan kebangkitan ekonomi secara menyeluruh.

Melihat dari heteregonitas persoalan di masinh-masing industri, maka tidak bisa diambil langkah kebijakan yang homogintas, tapi kebijakan yang diambil bertumpuh pada keunggulan masingmasing (compative advantage). Kelebihan dan kekurangan masing- masing antar organisasi dimaknai pada sisi saing mensubtitusi atau bersifat saling mensubsidi dan melengkapi.

\section{DAFTAR PUSTAKA}

Argenti, Paul (2009). Corporate Communication. Salemba Humanika: Jakarta

Dampak Pandemi Covid 19 Pada Berbagai Sektor Bisnis. Diambil Juli, 2020. Dari https://teknoia.com/dampak-covid-19-padabisnis-84dba2cc6727

Fajar, Arief Juli. (2011). Sistem Kendali dan Strategi Penanganan (Manajemen) Krisis dalam Kajian Public Relations. Jurnal ASPIKOM Komunikasi. Volume 1, Nomor 3; Yogyakarta.

Fink, Steven. (2000). Crisis Communications; The Definitive Guide To Managing The Message: Universe: USA

Hafid, Maret. (2020). Kenali Manajemen Krisis Perusahaan di Tengah Pandemi. Jurnal Online Entrepreneur.

Ikhsan, Mohammad. (2020). Memetakan Jalan Penguatan Ekonomi Pasca Pandemi. The
Indonesian Journal of Development Planning Volume IV no 2 Juni 2020.

Local Economic Impact Report. Diambil Juni, 2020

Dari https://www.yelpeconomicaverage.com/busi ness-closures-update-sep-2020

Kristian, Aknolt. (2020). JIHI; Jurnal Ilmiah Hubungan Internasional; journal.unpar.ac.id

Pasardana.id, Juli, 2020. Lima Langka Transformasi Industri Selama Pandemi Covid 19.

Puji, Hendra. (2020). Opini: Perubahan Sosial di Era Pandemi. Lombok post: Nusa Tenggara Barat.

WHO Ingatkan Dunia Harus Siap Pandemi Berikutnya. Diambil September, 2020 Dari https://health.detik.com/berita-detikhealth/d5163816/who-ingatkan-dunia-harus-siappandemi-berikutnya

Strategi Mempertahankan Bisnis di Tengah Pandemi Covid- 19. Jakarta Diambil April, 2020

Dari

https://inforial.tempo.co/info/1002932/strate gi-mempertahankan-bisnis-di-tengahpandemi-covid-19

Tan, Dita. W, 2011. The Art of War Sun Tzu : Seni Perang Dunia Bisnis. Immortal Publisher: Yogyakarta. 